\title{
Wybrane cechy realizacji adaptatorów w narracji dzieci i dorosłych
}

\section{Selectedfeatures of adaptorsin narratives of children and adults}

\author{
Ewa Jarmołowicz-Nowikow \\ INSTYTUT JEZZYKOZNAWSTWA, UNIWERSYTET IM. ADAMA MICKIEWICZA \\ AL. NIEPODLEGŁOŚCI 4, 61-874 POZNAŃ \\ ewa@jarmolowicz.art.pl \\ Abstract
}

The aim of the paper is to describe selected features of nonverbal behaviors defined as adaptors during cartoon narration by children and adults. Ten nine-year-old children and ten adults took part in the study. The results of the analysis of the material showed that: 1 . children used more adaptors than adults, 2. the average time confessed to the production of adaptors by children was longer than by adults, 3. children more often than adults produced two co-occurring adaptors of different types.

\section{Zachowania (nie)komunikacyjne?}

Zachowanie niewerbalne jest pojęciem znacznie szerszym niż gest. Obejmuje ono ogół ruchów realizowanych przez człowieka rękoma, nogami, głową, poprzez spojrzenie, zmianę postawy (Ekman i Friesen 1969: 49). W literaturze poświęconej niewerbalnemu aspektowi wypowiedzi często proponuje się podział zachowań niewerbalnych na dwie główne klasy. Jedną z nich tworzą zachowania definiowane jako ruchy rąk lub innych części ciała pozostające $\mathrm{w}$ bezpośrednim związku z treścią, a także prozodią ustnej wypowiedzi i które odbierane są przez rozmówców jako efekt zamierzonego wysiłku komunikacyjnego (Kendon 2005: 15). Określane są one jako gesty. Drugą kategorię stanowią zachowania niewerbalne, których relacja $\mathrm{z}$ wypowiedzią werbalną jest znacznie trudniejsza do zdefiniowania. Określane są one w literaturze jako zachowania adaptacyjne (ang. adaptors) (Ekman i Friesen: 1969), zachowania samodotykowe (Morris 1998: 231), głaski, samogłaski (Antas 2013: 52), ruchy skoncentrowane na ciele (ang. body-focusedmovements) (Freedman i Hoffman 1967).

Badania prowadzone przez lingwistów koncentrują się głównie na pierwszej wspomnianej kategorii zachowań niewerbalnych, czyli gestach, co znajduje 
swoje odzwierciedlenie $\mathrm{w}$ proponowanych przez nich klasyfikacjach obejmujących niewerbalne zachowania komunikacyjne (np. McNeill, 1992). Druga kategoria stanowi głównie przedmiot badań psychologów (Freedman 1972, Lausberg 2013). Zachowania adaptacyjne stanowią kategorię znacznie słabiej poznaną przez badaczy niż gesty. Interpretacja ich funkcji pozostaje często w sferze spekulacji, a próby przypisywania im konkretnych znaczeń budzą liczne kontrowersje. Wspomniane problemy wynikają najprawdopodobniej z ogromnej heterogeniczności adaptatorów. Należy jednak podkreślić, że mimo wielu trudności wiążących się z próbą opisu ich struktury, stanowią one grupę łatwo odróżnialną od gestów (Bavelas, Chovil, Coates i Roe 1995).

Ekman i Friesen (1969) nazwali omawiane ruchy adaptorami, ponieważ ich zdaniem, pierwotnie służą zaspakajaniu potrzeb związanych z szeroko rozumianą adaptacją. Cel realizacji adaptatorów jest oczywisty u małych dzieci. Są one realizowane $m$. in. po to, aby nie doszło do odebrania poprzez słuch, wzrok, węch, smak, dotyk niektórych bodźców (np. zatykanie nosa), aby ukryć pewne reakcje (np. płacz, śmiech), stać się bardziej atrakcyjnym (poprawianie włosów). Wraz z rozwojem dziecka ulegają one stopniowym modyfikacjom i redukcjom formy - realizowane przez osoby dorosłe stanowią tylko część pierwotnego zachowania, nie zawsze pozostającego $\mathrm{w}$ oczywistym związku z pierwotnym celem jego realizacji. Wraz z wiekiem część tego typu zachowań jest coraz bardziej ograniczana, co jest spowodowane m.in. większą świadomością ich niestosowności podczas komunikacji, zahamowaniami związanymi z ich realizacją (Ekman i Friesen 1969).

Ekman i Friesen (1969: 85-92) wyróżnili trzy podkategorie adaptatorów:

$>$ Zachowania autoadaptacyjne

$>$ Zachowaiaalteradaptacyjne

$>$ Zachowania z wykorzystaniem przedmiotu.

Kryterium podziału jest obiekt, na który ukierunkowany lub z którym związany jest ruch. W przypadku zachowanaautoadaptacyjnych jest to własne ciało (np. pocieranie dłoni o dłoń, poruszanie nogą), alteradaptacyjnych interlokutor (np. ruch brania, dawania), a w przypadku zachowań z wykorzystaniem przedmiotu - przedmiot (np. pstrykanie długopisem).

Zachowania autoadaptacyjne, a w szczególności te, które stanowią zachowania samodotykowe, w trakcie których dochodzi do kontaktu między poszczególnymi częściami ciała mówcy (np. jedna dłoń szczypie palce drugiej dłoni, dłoń gładzi drugą dłoń) stanowią najlepiej zbadaną grupę wśród adaptatorów.

Według Ekmana i Friesena (1969: 91) większość adaptatorów, a w szczególności autoadaptatorów, realizuje się z niewielką świadomością i bez intencji komunikacyjnej. Mimo to podlegają one często interpretacji ze strony odbiorcy, który na ich podstawie wyciąga wnioski na przykład na 
temat stanu emocjonalnego interlokutora. Mogą wywoływać reakcję zwrotna ze strony interlokutora.

Wiele badań poświęconych autoadaptorom oparto na materiale pochodzącym z sesji terapeutycznych czy wywiadów psychiatrycznych (np. Freedman 1972, Troisi i inni 2000, Lausberg 2013). Analizy materiałów filmowych pokazują, że autoadaptatory - szczególnie te, które nie są pojedynczym ruchem, a które stanowią powtarzającą się sekwencję ruchów tego samego typu - mogą redukować stres (np. Ekman i Friesen 1969; Freedman 1972, Waxer 1977, Freedman i Bucci 1981, Mohiyeddini, Bauer i Semple2013). Zauważono bowiem, że bardzo często są realizowane w sytuacji potencjalnie go wywołującej. Przypuszcza się także, że forma autoadaptatorów może mieć związek z poziomem doświadczanego stresu i nastawieniem mówcy do odbiorcy (Freedman i Hoffman 1972: 172). Freedman i Hoffman (1972) zauważyli także, że różne typy autoadaptatorów, wyróżnione na podstawie rodzaju realizowanego ruchu, mogą wskazywać na wewnętrzny konflikt doświadczany przez pacjenta między tym co wypowiedziane i tym co nie wypowiedziane (Freedman i Hoffman 1972: 172). Na podstawie analiz zachowań pacjentów odbywających terapię zauważyli, że zachowania autoadaptacyjne pojawiają się często $\mathrm{w}$ sytuacji braku woli lub umiejętności zwerbalizowania doświadczenia związanego $\mathrm{z}$ tematem wypowiedzi. Zauważono także związek między sytuacją, w której dochodzi u osoby badanej do podzielności uwagi a realizacją ruchów samodotykowych (Freedman i Hoffman 1972, 1967; Lausberg 2013).

Wspomniane powyżej badania podkreślają związek adaptatorów ze stanem psychicznym, przeżywanymi emocjami, przedstawiają ten rodzaj zachowań niewerbalnych jako niezwiązanych z wypowiedzią werbalną. Istnieją jednak badania koncentrujące się na pragmalingwistycznym aspekcie relacji między adaptatorami a wypowiedzią. Badania te sugerują wpływ autoadaptatorów na przebieg interakcji między uczestnikami dialogu. Orzechowski, Żywiczyński i Wacewicz (2017) w badaniu z zastosowaniem okulografu podjęli próbę ustalenia, jak często interlokutor patrzy na twarz, gesty czy zachowania samodotykowe rozmówcy. Analizy materiału filmowego pokazały, że badani skupiali spojrzenie głównie na twarzy rozmówcy, a częściej niż na gesty patrzyli na zachowania samodotykowe. Inne badania przeprowadzone przez wspomnianych badaczy (Żywiczyński, Wacewicz i Orzechowski, 2017) wykazały związek między częstością adaptatorów dyskretnych (Freedman 1972), trwających krócej niż trzy sekundy i strukturą wypowiedzi. Zauważono, że uczestnicy badania częściej wykonywali dyskretne adaptatory tuż przed zmianą tury konwersacyjnej.

\section{Cel badania}

Celem badania jest analiza wybranych elementów realizacji zachowań niewerbalnych, definiowanych jako adaptatory (Ekman i Friesen 1969), w trakcie opowiadania bajki przez dzieci i dorosłych. Opisywane i analizowane elementy stanowią składowe intensywnościzachowańniewerbalnych. Według Poggi i Pelachaud (2008: 395) gesty mogą być wykonywane mniej 
Ewa Jarmołowicz-Nowikow: Wybrane cechy realizacji adaptatorów $w$ narracji dzieci i dorostych

lub bardziej intensywnie. Intensywność wykonania gestu zależy od kilku elementów kinematyki i dynamiki jego realizacji, w tym od stopnia wykorzystywanej przez gest przestrzeni, tempa jego realizacji.

Analiza wybranych cech adaptatorów uwzględniała dwa parametry intensywności realizacji:

$>$ czas przeznaczony na produkcję adaptatorów podczas trwania dialogu,

$>$ liczbę realizowanych adaptatorów,

> współwystępowanie adaptatorów realizowanych rękoma z innymi ruchami adaptacyjnymi.

Istotnym parametrem intensywności zachowań niewerbalnych, który nie został wzięty pod uwagę jest amplituda ich realizacji. Adaptatory ze względu na swoją specyfikę są jednak ruchami z reguły o niewielkiej amplitudzie. Wstępny przegląd zgromadzonego materiału pokazał, że są one realizowane $\mathrm{w}$ jednej strefie gestykulacyjnej (McNeill 1992), a wiele $\mathrm{z}$ nich to mikroruchy.

Przypuszczenie dotyczące potencjalnych różnic w realizacji adaptatorów przez dzieci i dorosłych ma swoje źródło w: 1. potwierdzonych licznymi badaniami i obserwacjami wynikach, które wskazują na różnice w sposobie realizacji komunikacyjnych zachowań niewerbalnych u dzieci i dorosłych (Iverson i Goldin-Meadow 2005), 2. zakładanej przez Ekmana i Friesena (1969) coraz większej wraz z wiekiem świadomość niestosowności związanej z obecnością adaptatorów w dialogu, 3. różnym sposobie reagowania na stres w zależności od wieku w sytuacji mówienia przed grupą odbiorców (np. Kudielka, Buske-Kirschbaum, Hellhammer, Kirschbaum 2000).

\section{Analizowany materiał oraz procedura badania}

Analizowany materiał składa się $\mathrm{z}$ dziesięciu zarejestrowanych sesjiz udziałem dziewięcioletnich dzieci (pięć dziewczynek i pięciu chłopców) oraz 10 sesji z udziałem dorosłych (pięć kobiet i pięć mężczyzn). Czas trwania analizowanych sesji był różny (od cztery do siedmiu minut). Był on zależny od dynamiki narracji badanej osoby. Łączny czas trwania wszystkich sesji udziałem dzieci oraz wszystkich sesji z udziałem dorosłych był zbliżony (łączny czas sesji z udziałem dzieci to 52 minuty i 40 sekund, a z udziałem dorosłych 54 minuty i 49 sekund).

Materiał zarejestrowano w ramach projektu „Komplementarność niewerbalnych i werbalnych składników wypowiedzi: Analiza porównawcza dzieci i dorosłych.”1 Scenariusz nagrania zaprojektowano na podstawie

${ }^{1}$ Projekt (DWM/N 64/COST/2008) realizowany w latach 2008-2009 w Interdyscyplinarnym Centrum Przetwarzania Mowy i Języka UAM 
procedury badawczej opracowanej w laboratorium Davida McNeilla (University of Chicago), wielokrotnie wykorzystywanej w innych ośrodkach m.in. w celu zbadania sposobów obrazowania wybranych elementów treści wypowiedzi, analiz rozwoju zachowań niewerbalnych dzieci, a także różnic kulturowych przejawiających się na poziomie realizacji gestów (np. Duncan, 2001).

Wykorzystane w przedstawionych badaniach nagrania zawierały dialogi między osobą badaną i odpowiednio przygotowanym dorosłym rozmówcą. Zadaniem osoby badanej było obejrzenie wybranego filmu animowanego $\mathrm{z}$ serii o kocie Sylwestrze i ptaszku Tweety (ten sam film był wykorzystywany w pozostałych badaniach), i następnie opowiedzenie jej treści rozmówcy. Osoba podstawiona, gdy zachodziła taka potrzeba, zadawała dodatkowe pytania o szczegóły związane z treścią filmu. Pytania podnosiły dynamikę dialogu, a treść przedstawiana przez badaną osobę zyskiwała na szczegółowości i uporządkowaniu. Zadawanie dodatkowych pytań było szczególnie istotne podczas nagrywania materiału z udziałem dzieci.

\section{Sposób opisania materiału}

Nagrania opisano w programie Elan (Sloetjes i Wittenburg2008), który umożliwia anotację materiału filmowego na dowolnej liczbie poziomów. Zachowania uczestników badania zostały podzielone na dwie główne kategorie: gesty oraz adaptatory.

Gesty opisano zgodnie z zaproponowanym przez Kendona(1972) i rozszerzonym przez Kitę (1990)modelem struktury gestu. Ponieważ nie jest możliwe zastosowanie do opisu adaptatorów modelu typowego dla struktury gestu, adaptatory opisywane były jako jednostki zawierające podobny rodzaj powtarzającego się ruchu, na przykład szczypania, gładzenia.

Adaptatory wykonywane dłońmi w stosunku do innych zachowań adaptacyjnych stanowiły grupę dominującą biorąc pod uwagę zarówno liczbę realizowanych jednostek jak i czas ich trwania. Dlatego też analizy dotyczące czasu przeznaczonego na realizację adaptatorów koncentrowały się na ruchach dłoni. Inne adaptatory, realizowane na przykład nogami, były traktowane jako zachowania adaptacyjne współwystępujące i brano je pod uwagę tylko podczas analiz współwystępowania zachowań adaptacyjnych.

\section{Analizy oraz wyniki}

Adaptatory i gesty to typy zachowań niewerbalnych charakteryzujące się różną funkcją i strukturą. W przeciwieństwie do gestów, które z reguły współwystępują z wypowiedzią werbalną, adaptatory realizowane są także 
Ewa Jarmołowicz-Nowikow: Wybrane cechy realizacji adaptatorów $w$ narracji dzieci i dorostych

bez równoległej mowy, na przykład podczas słuchania pytania zadawanego przez rozmówcę. W przedstawianych analizach zastosowano dwa kryteria porównania częstości użycia adaptatorów i gestów:

$>$ odsetek czasu trwania sesji przypadający na wykonywanie adaptatorów oraz gestów

$>$ liczba adaptatorów oraz gestów przypadających na jednostkę czasu.

Łączny czas dziesięciu sesji z udziałem dzieci to około 53 minuty, natomiast dziesięć sesji z udziałem dorosłych około 55 minut. Dzieci wykonały w sumie 219 adaptatorów realizowanych rękoma (dziewczynki 117, chłopcy 102) i 201 gestów (dziewczynki 111, chłopcy 90). Dorośli wykonali 135 adaptatorów (kobiety 65, mężczyźni 70) i 608 gestów (321 kobiety i 287 mężczý́ni).

Analiza sesji pokazała, że dzieci w trakcie trwania rozmowy na temat obejrzanego filmu animowanego częściej niż dorośli wykonywały jakikolwiek ruch rękoma. Łączny czas, w którym odnotowano u dzieci zachowania niewerbalne rąk to około 45 minut, czyli $85 \%$ czasu trwania analizowanych sesji z udziałem dzieci, natomiast u dorosłych około 29 minut, czyli 53\% czasu trwania sesji.

Analiza zachowań niewerbalnych przeprowadzona dla każdego mówcy pokazała, że dzieci przeznaczają istotnie więcej czasu na realizację adaptatorów niż dorośli. Wszystkie dzieci realizowały adaptatory przez ponad 50\% czasu trwania dialogu. Łączny czas przeznaczony na realizację adaptatorów wyniósł w przypadku dzieci od 62\% do 93\% czasu dialogu. W grupie dorosłych tylko jedna osoba wykonywała adaptatory przez więcej niż połowę czasu trwania dialogu (67\% czasu trwania dialogu).

Różnice między dziećmi i dorosłymi dotyczyły także proporcji między czasem przeznaczonym na wykonywanie adaptatorów i gestów. W analizowanym materiale $\mathrm{z}$ udziałem dzieci w każdej z dziecięciu sesji czas przeznaczony na adaptatory był dłuższy niż przeznaczony na gesty. Taka sytuacja miała miejsce w 5 analizowanych sesjach z udziałem dorosłych. Adaptatory wykonywane dłońmi i gesty nie były realizowane w tym samym czasie, tzn. ani razu w analizowanym materiale nie pojawiła się sytuacja, w której osoba badana jedną ręką wykonywałaby adaptator, a drugą gest. 


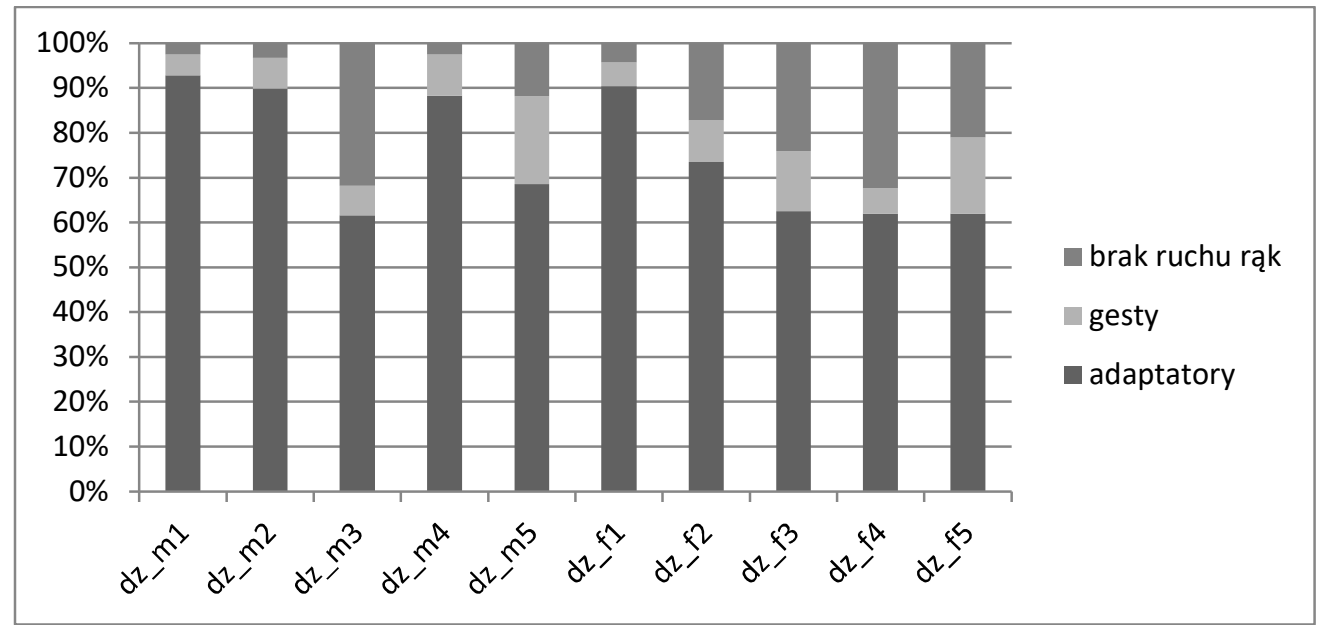

Ryc. 1 Procent łącznego czasu trwania adaptatorów, gestów oraz braku ruchu rąk dla poszczególnych dzieci

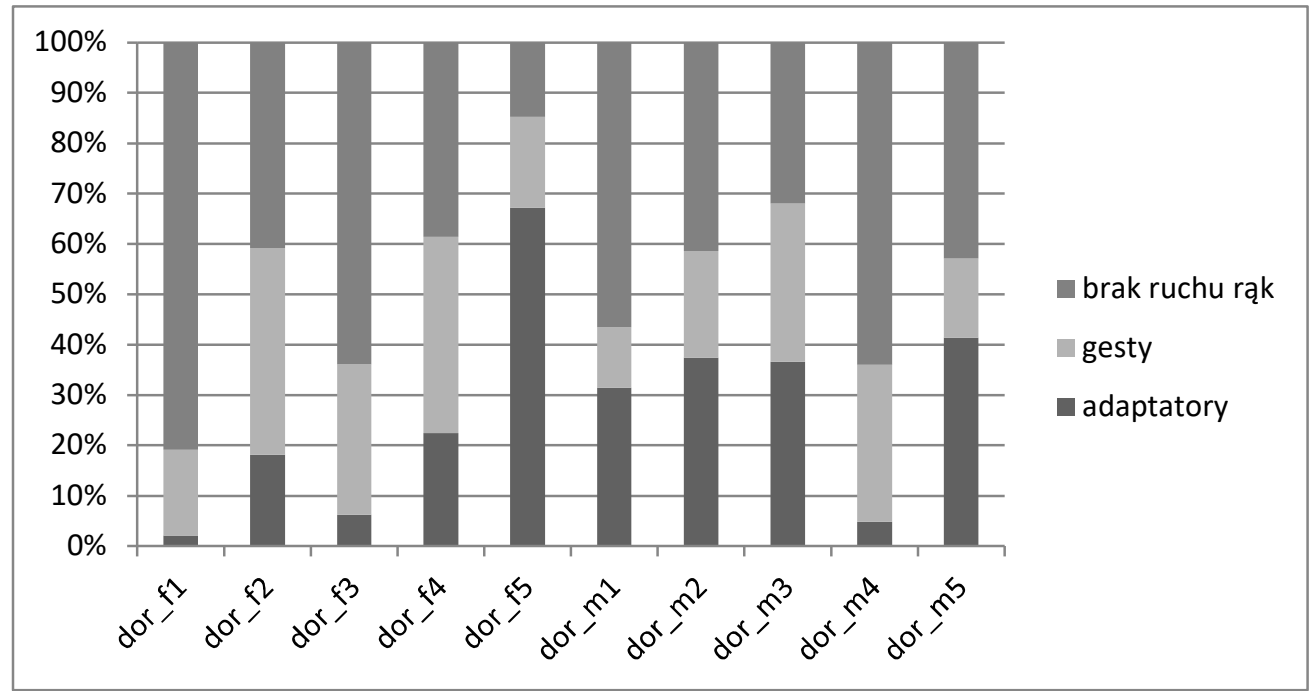

Ryc. 2 Procent tacznego czasu trwania adaptatorów, gestów oraz braku ruchu rąk dla poszczególnych dorostych

Różnice widać także między łącznym czasem realizacji adaptatorów i gestów w grupie dzieci i grupie dorosłych. Łączny czas realizacji adaptatorów przez dzieci wyniósł około 40 minut, czyli $75 \%$ całkowitego czasu trwania wszystkich dialogów z ich udziałem. Łączny czas realizacji gestów w grupie dzieci był krótszy. Wyniósł 5 minut, czyli 9\% czasu trwania dialogów. Z kolei łączny czas realizacji adaptatorów przez dorosłych wyniósł 14 minut i 39 sekund, czyli $27 \%$ całkowitego czasu trwania wszystkich dialogów z udziałem dorosłych. Czas realizacji gestów przez osoby dorosłe wyniósł łącznie 14 minut i 32 sekundy, czyli 26\% czasu trwania dialogów. Analizy 
Ewa Jarmołowicz-Nowikow: Wybrane cechy realizacji adaptatorów $w$ narracji dzieci i dorostych

uwzględniające płeć badanych pokazały także, że najkrótszy łączny czas przeznaczony na realizację adaptatorów (23\%), a proporcjonalnie najdłuższy łączny czas wykonywania gestów (29\%) odnotowano u dorosłych kobiet. Najdłuższy średni czas realizacji adaptatorów (80\%) i najkrótszy czas realizacji gestów (9\%) zmierzono u chłopców.

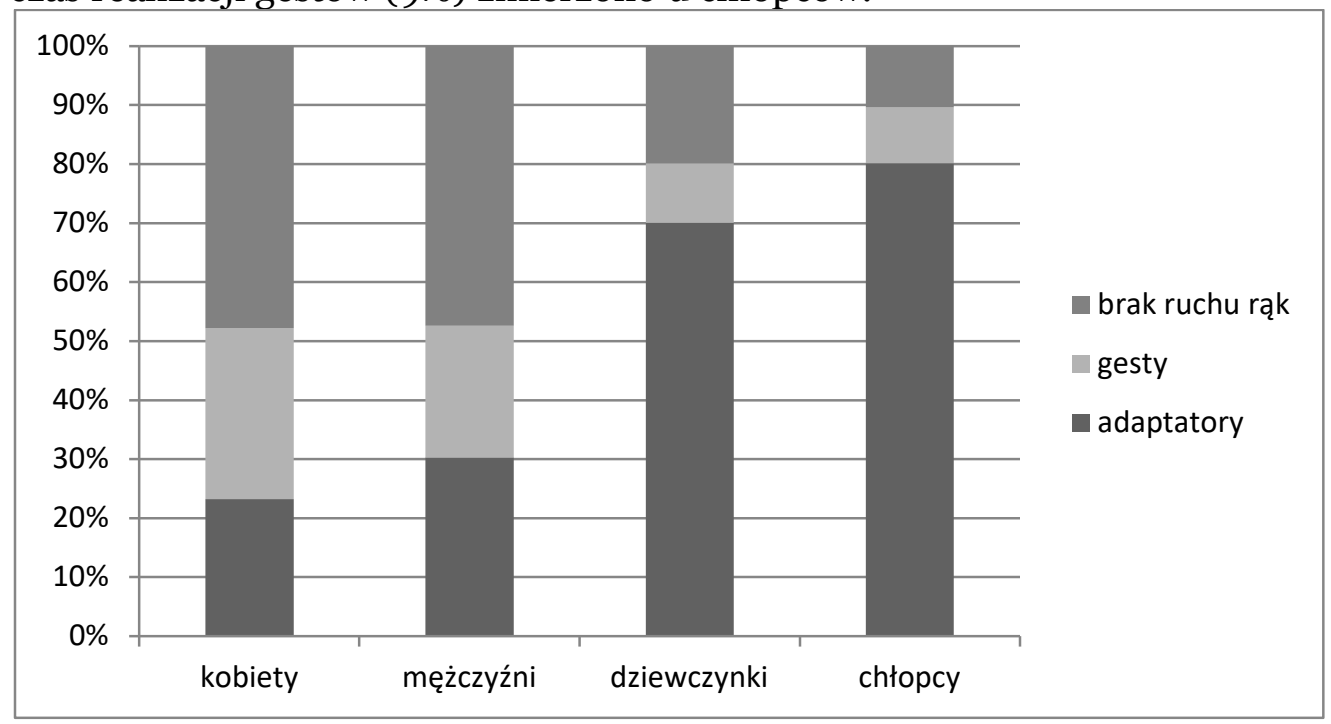

Ryc.3Proporcje łącznego czasu trwania poszczególnych kategorii zachowań niewerbalnych.

Średni czas trwania adaptatora wyniósł (po odrzuceniu odstających) 7,8 s (odch. stand. 5,9 s) dla dzieci i 6,3 s (odch. stand. 4,8 s) dla dorosłych. Ze względu na rozkłady wartości zmiennej, które nie spełniały dla żadnej z grup warunku normalności, zastosowano test nieparametryczny (U MannaWhitney’a). Jego wynik wskazuje na istotną różnicę między wartościami zmiennej dla dzieci i dorosłych $(p=0,001)$. Nie stwierdzono w grupie dorosłych ani w grupie dzieci istotnych statystycznie różnic w czasach trwania adaptatorów między płciami. Podobne analizy dla gestów pozwoliły ustalić, że między czasami ich realizacji u dzieci (średnia 1,51 sekundy, odch. stand. 0,95 sekundy) i u dorosłych ('́rednia 1,55 sekundy, odch. stand. 0,97) nie zachodzi istotna statystycznie różnica. 

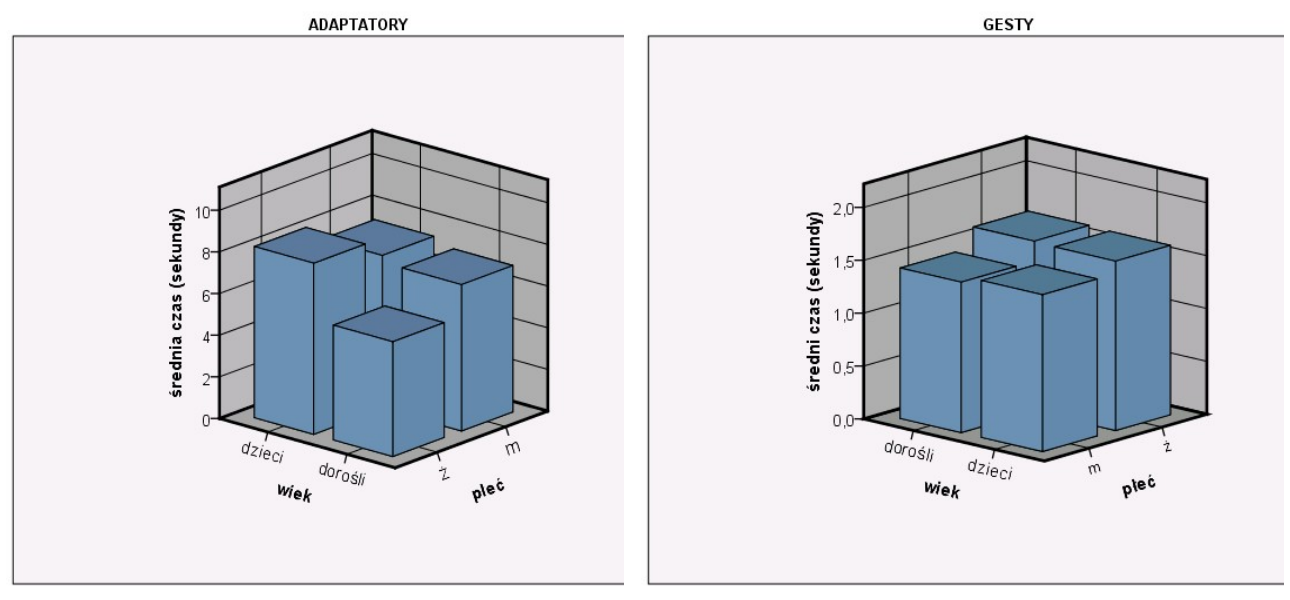

Ryc. 4. Średnie czasy trwania adaptatorów (lewy panel) i gestów (prawy panel) w podziale na grupy wiekowe i pleć

Porównano także średnią liczbę gestów i adaptatorów na minutę czasu sesji oraz na minutę wypowiedzi u dorosłych i dzieci. Do czasu trwania wypowiedzi wliczono lączny czas wszystkich fraz intonacyjnych (w tym niedokończonych i zaburzonych) zrealizowanych przez daną osobę w czasie sesji. Zarówno w odniesieniu do czasu całej sesji, jak i w stosunku do czasu trwania wypowiedzi są widoczne podobne zależności dotyczące liczby gestów i adaptatorów w dwóch grupach wiekowych. Dorośli wykonywali przeciętnie ponad pięć razy więcej gestów niż adaptatorów, podczas gdy liczba gestów i adaptatorów u dzieci była zbliżona, zarówno w przeliczeniu na czas całej sesji, jak i w stosunku do czasu ich wypowiedzi.

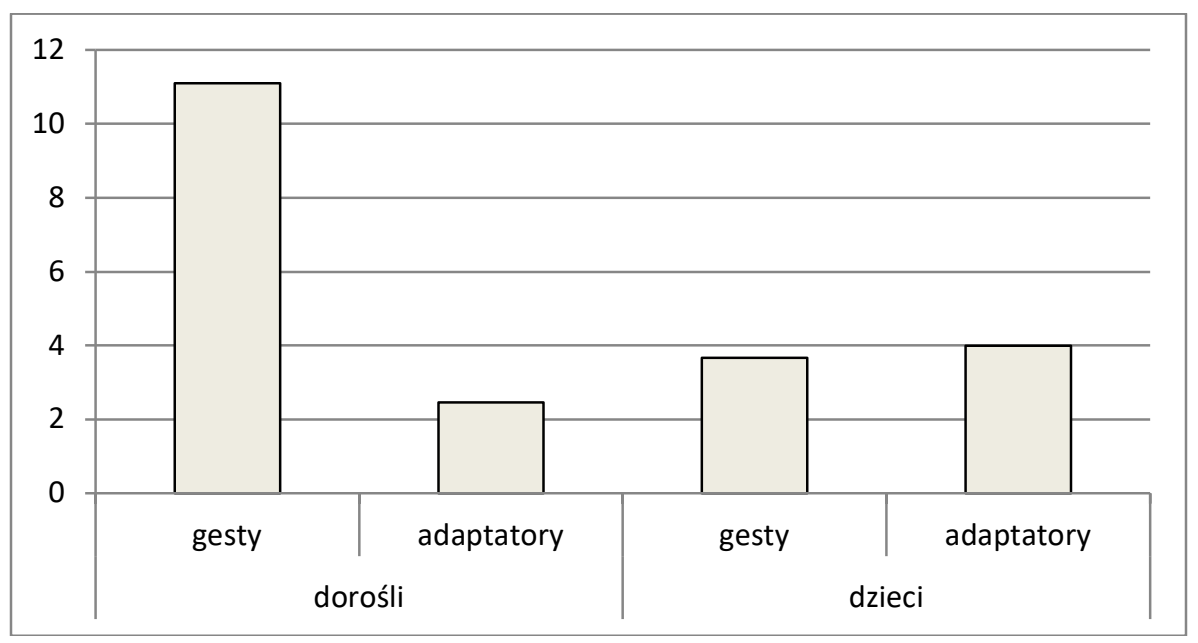

Ryc. 5. Średnia liczba zachowań niewerbalnych (gestów i adaptatorów) na minutę czasu sesji u dorostych i dzieci 
Ewa Jarmolowicz-Nowikow: Wybrane cechy realizacji adaptatorów w narracji dzieci i dorostych

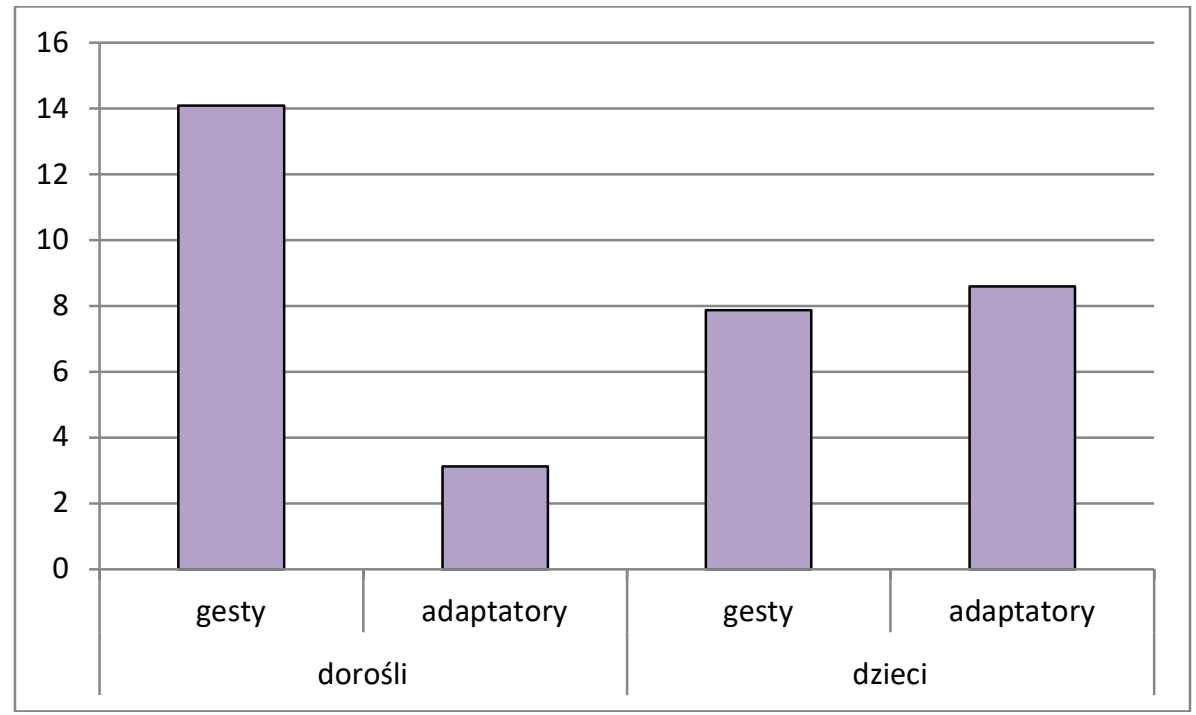

Ryc. 6. Średnia liczba zachowań niewerbalnych (gestów i adaptatorów) na minutę wypowiedzi u dorostych i dzieci

Sprawdzono także, czy adaptatory realizowane dłońmi przez dzieci i dorosłych współwystępują z innymi zachowaniami adaptacyjnymi. Na podstawie wstępnej obserwacji wyróżniono trzy kategorie adaptatorów, które współwystępują z adaptatorami wykonywanymi rękoma. Wyróżnione kategorie to: 1 . adaptatory wykonywane nogami, 2. poprawianie pozycji na krześle, 3. kołysanie się na krześle. Adaptatory współwystępujące rozpoczynały się i kończyły $\mathrm{w}$ czasie trwania adaptatorów realizowanych ręką. Wyniki analiz pokazały, że najczęściej współrealizowanymi z adaptatorami realizowanymi dłońmi były adaptatory realizowane nogami. Analizowane ruchy nóg polegały na powtarzającym się ruchu jednej lub obu nóg (na przykład wymachiwaniu) lub pocieraniu stopą podłogi. Badane dzieci realizowały adaptatory nogami częściej niż dorośli. Były one obecne w $44 \%$ relizowanych przez dzieci adaptatorach, a u dorosłych w $21 \%$. 


\section{InvestigationesLinguisticae, vol. XLII}

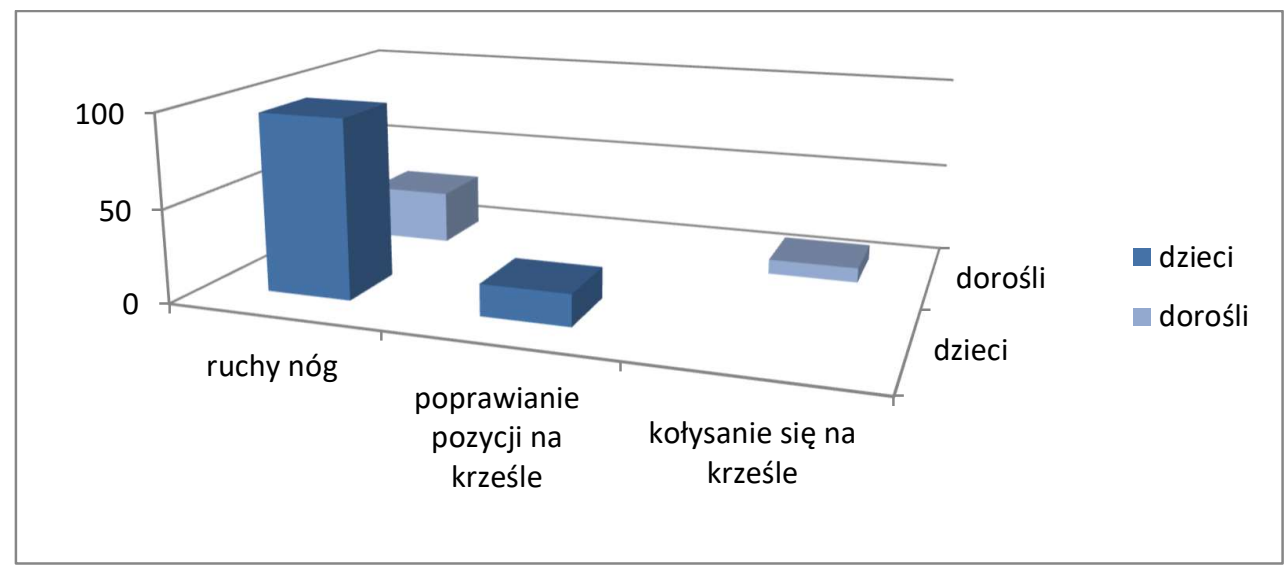

Ryc. 7.Liczby bezwzględne adaptatorów współwystęujących z adaptatorami realizowanymi rękoma

\section{Podsumowanie}

Przeprowadzone badania koncentrowały się na trzech cechach realizacji adaptatorów: częstości ich występowania, czasie przeznaczonym na ich realizację $\mathrm{w}$ stosunku do czasu całej sesji oraz współwystępowaniu $\mathrm{z}$ adaptatorami wykonywanymi innymi częściami ciała niż ręce. Analiza wybranych cech adaptatorów pokazała większą intensywność ich użycia w grupie dzieci niż w grupie dorosłych. Łączny czas realizacji analizowanych zachowańw grupie dzieci był dłuższy, a ich liczba na minutę sesji czy wypowiedzi większa. Dzieci częściej niż dorośli wykonywały równolegle dwa adaptatory.

Trudno jednoznacznie wytłumaczyć większą intensywność adaptatorów u badanych dzieci niż dorosłych. Obecność adaptatorów u osób badanych można najprawdopodobniej uzasadnić obecnością emocji, które pojawiają się w trakcie wypowiedzi publicznej. Złożonym problemem jest natomiast sposób reagowania przez dzieci i dorosłych na stres wywołany wypowiedzią w trakcie badania. Badania fizjologicznych reakcji dzieci i dorosłych na stres wywołany wystąpieniem publicznym pokazują, że z jednej strony zauważa się u dzieci szybszy niż u dorosłych puls w opisywanej sytuacji (Kudielka, Buske-Kirschbaum, Hellhammer i Kirschbaum, 2004), z drugiej strony badania (Yim, Quas, Cahill i Hayakawa, 2010) wykazują podobny poziom kortyzolu w ślinie zarówno u dzieci jak i dorosłych, gdy poddani są identycznemu czynnikowi stresu psychospołecznego. Yim, Quas, Cahill i Hayakawa (2010) podkreślają jednak, że tym co najbardziej różni dzieci i dorosłych w sytuacji stresu wynikającego m. in. z wystąpień publicznych są reakcje behawioralne, okazywanie odczuwanych emocji poprzez zachowania niewerbalne, na przykład samodotykowe ruchy rąk. Można przypuszczać, że dzieci słabiej radzą sobie z kontrolowaniem, maskowaniem niewerbalnych przejawów stresu. Być może jest to wynik nierozwiniętej jeszcze umiejętności panowania nad zachowaniami obecnymi podczas procesu komunikacji lub niedostatecznie rozwiniętej kompetencji 
Ewa Jarmołowicz-Nowikow: Wybrane cechy realizacji adaptatorów w narracji dzieci i dorosłych

komunikacyjnej. Dziewięcioletnie dzieci wiedzą już, że realizacja gestu w strefie niewidocznej dla odbiorcy, na przykład za jego plecami, może nie być zauważona przez rozmówcę (McNeill 1992), lecz nie do końca panują jeszcze nad zachowaniami zdradzającymi ich stan emocjonalny.

Adaptatory nie są zachowaniami komunikacyjnymi, ale informatywnymi (Ekman, Friesen 1969). Ich wykonywanie nie jest intencjonalne komunikacyjnie, mówca poprzez ich realizację nie przekazuje treści związanych $\mathrm{z}$ wypowiedzią. Mogą być jednak interpretowane przez rozmówcę jako oznaki przeżywanych emocji. Intensywność realizacji adaptatorów może wpływać na sposób odbioru wypowiedzi przez interlokutora. Dalsze analizy opisanego w artykule materiału zakładają sprawdzenie, czy istnieje związek między stwierdzoną na podstawie analizy materiału większą intensywnością realizacji adaptatorów u dzieci i postrzeganiem ich zachowania jako bardziej nerwowego niż zachowanie dorosłych. 


\section{InvestigationesLinguisticae, vol. XLII}

\section{Bibliografia}

Antas, J. (2013). Semantyczność ciała. Gesty jako znaki myślenia. Łódź: Primum Verbum.

Bavelas, J. B., Chovil, N., Coates, L. i Roe, L. (1995). Gestures Specialized for Dialogie. Personality and social psychology bulletin, 21(4), strony 394405 .

Dittmann, A. T. (1962). The relationship between body movements and moods in interviews. Journal of Consulting Psychology, 26(5).

Duncan, S. (2001). Co-expressivity of speech and gesture: Manner of motion in Spanish, English, and Chinese. W Annual Meeting of the Berkeley Linguistics Society (Tom 27, strony 353--370).

Ekman, P. i Friesen, W. V. (1969). The repertoire of nonverbal behavior: Categories, origins, usage, and coding. Semiotica, 1(1), strony 49-98.

Freedman, N. (1972). The analysis of movement behavior during the clinical interview. W A. W. Siegman i B. Pope, Studies in Dyadic Communication (strony 153-175). New York, Toronto, Oxford, Sydney, Braunschweig: Pergamon Press.

Freedman, N. (1977). Hands, Words, and Mind: On the Structuralization of Body Movements During Discourse and the Capacity for Verbal Representation. W N. Freedman S. Grand, N. Freedman i S. Grand (Redaktorzy), Communicative structures and psychic structures (strony 109-132). Boston, MA: Springer.

Freedman, N. i Bucci, W. (1981). On kinetic filtering in associative monologue. Semiotica, 34(3-4), strony 225-250.

Freedman, N. i Hoffman, S. P. (1967). Kinetic behavior in altered clinical states: Approach to objective analysis of motor behavior during clinical interviews. Perceptual and motor skills, 24(2), strony 527-539.

Freedman, N. i Wilma, B. (1981). On kinetic filtering in associative monologue. Semiotica, 34(3-4), strony 225-250.

Freedman, N., Blass, T., Rifkin, A. i Quitkin, F. (1973). Body movements and the verbal encoding of aggressive affect. Journal of Personality and Social Psychology, 1.

Iverson, J. M. i Goldin-Meadow, S. (2005). Gesture paves the way for language development. Psychological science, 16(5), strony 367-371.

Jarmołowicz-Nowikow, E. (2009). Polish Children's Gesticulation in Narrating (Re-telling) a Cartoon. W R. Vich i A. Esposito, Cross-Modal Analysis of 


\section{Ewa Jarmołowicz-Nowikow: Wybrane cechy realizacji adaptatorów w narracji dzieci i dorostych}

Speech, Gestures, Gaze and Facial Expressions (strony 239-247). Berlin, Heidelberg: Springer.

Kendon, A. (1972). Some relationships between body motion and speech. W A. W. Siegman i B. Pope, Studies in dyadic communication (strony 177-210). New York: Pergamon Press.

Kendon, A. (2005). Gesture. Visible Action as Utterance (wyd. wydanie drugie). Cambridge: Cambridge University Press.

Kita, S. (1990). The temporal relationship between gesture and speech: A study of Japanese-English bilinguals. MS. Department of Psychology, University of Chicago.

Kudielka, B. M., Buske-Kirschbaum, A., Hellhammer, D. H. i Kirschbaum, C. (2004). Differential heart rate reactivity and recovery after psychosocial stress (TSST) in healthy children, younger adults, and elderly adults: the impact of age and gender. International Journal of Behavioral Medicine, 2, strony 116-121.

Lausberg, H. (2013). Understanding Body Movement: A Guide to Empirical Research on Nonverbal Behaviour : with an Introduction to the NEUROGES Coding System. (H. Lausberg, Red.) Frankfurt/Main: Peter Lang Verlag.

Maricchiolo, F. G. (2009). Effects of different types of hand gestures in persuasive speech on receivers' evaluations. Language and Cognitive Processes, 24(2), strony 239-266.

McNeill, D. (1992). Hand and mind: What gestures reveal about thought. Chicago, London: University of Chicago Press.

Mohiyeddini, C., Bauer, S. i Semple, S. (2013). Displacement behaviour is associated with reduced stress levels among men but not women. PloS one, 2, strony 384-392.

Morris, D. (1998). Zachowania intymne. Warszawa: Prima, Świat Książki.

Orzechowski, S., Żywiczyński, P. i Wacewicz, S. (2017, Wrzesień 26-28). Selftouching, gesticulations and attentional processes. An eye-tracking study. Book of Abstracts. Protolang 5. Barcelona. Pobrano Październik 1, 2017 z lokalizacji http://bioling.ub.edu/wpcontent/uploads/2017/o9/protolang5_book_of_abstracts.pdf

Poggi, I. i Pelachaud, C. (2008). Persuasion and the expressivity of gestures in humans and machines. Embodied communication in humans and machines, strony 391-424.

Sloetjes, H. i Wittenburg, P. (2008). Annotation by category - ELAN and ISO DCR. Proceedings of the 6th International Conference of Language Resources (LREC 2008), (strony 816-820). 
Troisi, A., Belsanti, S., Bucci, A. R., Mosco, C., Sinti, F. i Verucci, M. (2000). Affect regulation in alexithymia: an ethological study of displacement behavior during psychiatric interviews. The Journal of nervous and mental disease, 188(1), strony 13-18.

Waxer, P. H. (1977). Nonverbal cues for anxiety: An examination of emotional leakage. Journal of abnormal psychology, 86(3).

Yim, I. S., Quas, J. A., Cahill, L. i Hayakawa, C. M. (2010). Children's and adults' salivary cortisol responses to an identical psychosocial laboratory stressor. Psychoneuroendocrinology, 35(2), strony 241--248.

Żywiczyński, P., Wacewicz, S. i Orzechowski, S. (2017). Adaptors and the turntaking mechanism: The distribution of adaptors relative to turn borders in dyadic conversation. Interaction Studies. Social Behaviour and Communication in Biological and Artificial Systems, 18(2). 